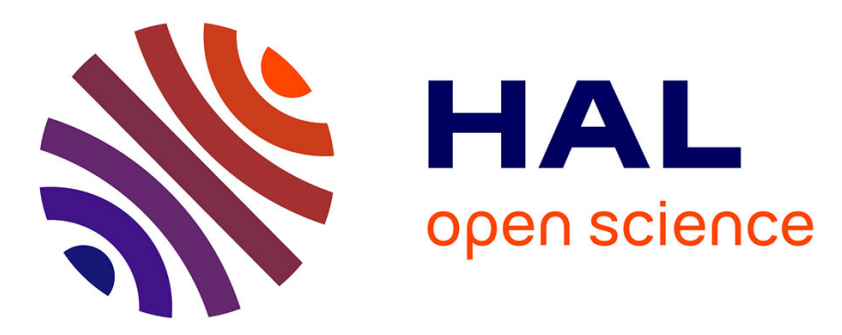

\title{
Lithological Architecture and Petrography of the Mako Birimian Greenstone Belt, Kédougou-Kéniéba Inlier, Eastern Senegal
}

Moussa Dabo, Tahar Aïfa, Ibrahima Gning, Malick Faye, Mamadou Fallou Ba, Papa Malick Ngom

\section{To cite this version:}

Moussa Dabo, Tahar Aïfa, Ibrahima Gning, Malick Faye, Mamadou Fallou Ba, et al.. Lithological Architecture and Petrography of the Mako Birimian Greenstone Belt, Kédougou-Kéniéba Inlier, Eastern Senegal. Journal of African Earth Sciences, 2017, 131, pp.128-144. 10.1016/j.jafrearsci.2017.04.005 . insu-01505991

\section{HAL Id: insu-01505991 https://hal-insu.archives-ouvertes.fr/insu-01505991}

Submitted on 12 Apr 2017

HAL is a multi-disciplinary open access archive for the deposit and dissemination of scientific research documents, whether they are published or not. The documents may come from teaching and research institutions in France or abroad, or from public or private research centers.
L'archive ouverte pluridisciplinaire HAL, est destinée au dépôt et à la diffusion de documents scientifiques de niveau recherche, publiés ou non, émanant des établissements d'enseignement et de recherche français ou étrangers, des laboratoires publics ou privés. 


\section{Accepted Manuscript}

Lithological Architecture and Petrography of the Mako Birimian Greenstone Belt, Kédougou-Kéniéba Inlier, Eastern Senegal

Moussa Dabo, Tahar Aïfa, Ibrahima Gning, Malick Faye, Mamadou Fallou Ba,

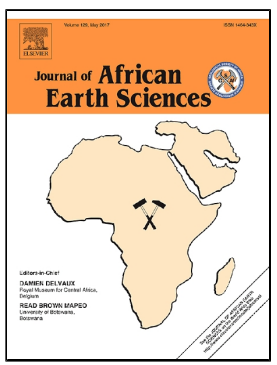
Papa Malick Ngom

PII: S1464-343X(17)30148-6

DOI: 10.1016/j.jafrearsci.2017.04.005

Reference: AES 2867

To appear in: Journal of African Earth Sciences

Received Date: 19 September 2016

Revised Date: 01 February 2017

Accepted Date: 06 April 2017

Please cite this article as: Moussa Dabo, Tahar Aïfa, Ibrahima Gning, Malick Faye, Mamadou Fallou Ba, Papa Malick Ngom, Lithological Architecture and Petrography of the Mako Birimian Greenstone Belt, Kédougou-Kéniéba Inlier, Eastern Senegal, Journal of African Earth Sciences (2017), doi: 10.1016/j.jafrearsci.2017.04.005

This is a PDF file of an unedited manuscript that has been accepted for publication. As a service to our customers we are providing this early version of the manuscript. The manuscript will undergo copyediting, typesetting, and review of the resulting proof before it is published in its final form. Please note that during the production process errors may be discovered which could affect the content, and all legal disclaimers that apply to the journal pertain. 
- A detailed succession of the magmatic events within the Birimian Kédougou-Kéniéba Inlier is performed;

- Ultramafic rocks are included in the metabasalts in pillow lavas, therefore older;

- Amphibole-gneisses are now located at the upper part of the ultramafic rocks;

- Occurrence of a second generation of metagabbros (spotted) post-ribboned quarzites

- A general two-phase metamorphism reaching the amphibolite facies is evidenced;

- Andesitic to felsic mixed volcanism (explosive and effusive) on top of the new lithology;

- Succession of facies and geochemical results from literature assume an ophiolite of active margins. 


\title{
Lithological Architecture and Petrography of the Mako Birimian Greenstone Belt, Kédougou-Kéniéba Inlier, Eastern Senegal
}

\author{
Moussa Dabo ${ }^{1,2}$, Tahar Aïfa ${ }^{2, *}$, Ibrahima Gning ${ }^{1}$, Malick Faye ${ }^{1}$, Mamadou Fallou Ba ${ }^{1}$, Papa \\ Malick Ngom ${ }^{1}$
}

${ }^{1}$ Département de Géologie, Faculté des Sciences et Techniques, Université Cheikh Anta Diop de Dakar, BP 5005, Dakar-Fann, Senegal

${ }^{2}$ Géosciences Rennes, CNRS UMR 6118, Université de Rennes 1, Bat.15, Campus de Beaulieu, 35042 Rennes Cedex, France

*Corresponding author: tahar.aifa@univ-rennes1.fr

\section{Abstract}

The new lithological and petrographic data obtained in the Mako sector are analyzed in the light of the geochemical data available in the literature. It consists of ultramaic, mafic rocks of tholeiitic affinities associated with intermediate and felsic rocks of calc-alkaline affinities and with intercalations of sedimentary rocks. The whole unit is intruded by Eburnean granitoids and affected by a greenschist to amphibolite facies metamorphism related to a high grade hydrothermalism. It consists of: (i) ultramafic rocks composed of a fractional crystallization succession of lherzolites, wehrlites and pyroxenites with mafic rock inclusions; (ii) layered, isotropic and pegmatitic metagabbros which gradually pass to metabasalts occur at the top; (iii) massive and in pillow metabasalts with locally tapered vesicles, completely or partially filled with quartzo-feldspathic minerals; (iv) quarzites locally overlying the mafic rocks and thus forming the top of the lower unit.

This ultramafic-mafic lower unit presents a tholeiitic affinity near to the OIB or N-MORB. It represents the Mako Ophiolitic Complex (MOC), a lithospheric fragment of Birimian lithospheric crust.

The upper unit is a mixed volcanic complex arranged in the tectonic corridors. From bottom to top it comprises the following: (i) andesitic, and (ii) rhyodacitic and rhyolitic lava flows and tuffs, respectively. They present a calc-alkaline affinity of the active margins.

Three generations of Eburnean granitoids are recognized: (i) early (2215-2160 Ma); (ii) syntectonics (2150-2100 Ma) and post-tectonics (2090-2040 Ma). The lithological succession, 
geochemical and metamorphic characteristics of these units point to an ophiolitic suprasubduction zone.

Keywords: Birimian, Mako, lithology, ophiolites, pillow lavas, supra-subduction.

\section{Introduction}

The $\sim 16000 \mathrm{~km}^{2}$ triangular shape of Kédougou-Kéniéba Inlier (KKI) represents the westernmost exposed part of the Leo-Man Birimian terrane, which straddles the border between Senegal and Mali on the West African Craton (WAC) (Fig. 1). The Birimian terrane represents a major Paleoproterozoic juvenile crust-forming event during a time interval of 2.25-2.0 Ga (Taylor et al., 1988, 1992; Abouchami et al., 1990; Liégeois et al., 1991; Hirdes et al., 1992, 1996). The Birimian greenstone belts are mainly constituted of bimodal volcanic rocks with tholeiitic ultramafic-mafic complex overlapped by calc-alkaline intermediate-felsic complex, both intruded by tonalite-trondhjemite-granodiorite (TTG) plutons (Dia et al., 1997; Pouclet et al. 2006, Attoh et al., 2006; Dampare et al., 2008; Delor et al., 2010; Ngom et al., 2011).

The importance of the Birimian geology in the crustal evolution and the geodynamic significance of the WAC has been a subject of much debate. Some researchers suggested that Birimian juvenile crust production occurred largely in arc environments (Sylvester and Attoh, 1992; Ama Salah et al., 1996; Dia et al., 1997; Diallo, 2001; Pawlig et al., 2006), while others proposed that it was a plume generated (Abouchami et al., 1990; Hirdes and Davis 2002; Ngom et al., 2011). In the plume model, rapid crustal growth was accomplished by a mantle plume event which formed extensive oceanic plateaus, while the island arc setting accounts for basalts with MORB affinities assembled together with oceanic island arcs during subduction processes (Attoh et al., 2006).

Ophiolite rock assemblages characterized the relict fragments of oceanic crust and upper mantle, were mainly viewed as formed at mid-ocean ridges. They are recognized in some Birimian greenstone belts of the WAC (Pouclet et al., 2006, Attoh et al., 2006; Dampare et al., 2008). Ophiolite assemblages within belts of accreted terranes indicate an oceanic origin for some terranes, associated with volcanic arc and volcaniclastic material, granitoids, and silicic extrusives that make a mid-ocean ridge origin suspect (Hawkins, 2003). All geologic units that characterize ophiolites are found in supra-subduction zone (SSZ) rock assemblages, as well as containing distinctive rock types, such as boninite and island arc rock series (Hawkins, 2003; Pearce, 2003). SSZ ophiolites have the structures or inferred structures of oceanic crust, 
68

69

70

yet a geochemical composition which indicates that they did not form mid-ocean ridges but at spreading centres associated with subduction zones (Pearce, 2003). Above the subduction zone, new oceanic crust is formed in the forearc, volcanic arc, and backarc basins (Hawkins, 2003). Paleoproterozoic Birimian greenstone belts of KKI are comprised of tholeiitic ultramafic-mafic basal complexes interstratified with calc-alkaline mafic-intermediate complex (Dia et al., 1997; Théveniaut et al., 2010; Ngom et al., 2011).

In this paper, we present new field and petrographic data of the Mako Birimian greenstone belt rocks in the westof KKI. The data were analyzed taking into account geochemical and geochronological data available in the literature (Diallo, 1994 Ngom, 1995; Dia et al., 1997; Gueye et al., 2008; Théveniaut et al., 2010). We propose a new lithological succession comprised of ultramafic-mafic tholeiitic basal complex with minor ultramafic rocks and major gabbro to basaltic rocks, surmounted by calc-alkaline intermediate-felsic complex made up of andesitic-dacitic-rhyodacitic and rhyolitic flows and pyroclastic rocks. Quartzitic lenses occurred interstratified with mafic rocks.

\section{Geological framework of the WAC}

The WAC (Fig. 1a) is dominated by volcanic and sedimentary Paleoproterozoic "Birimian" rocks (Taylor et al., 1988, 1992; Abouchami et al., 1990; Liegeois et al., 1991; Hirdes et al., 1992, 1996). In the Leo-Man shield, representing the southern part of the WAC, Birimian terranes consist of parallel and evenly spaced, NE-SW- to ENE-WSW- trending volcanic belts separated by sedimentary basins (Fig. 1a) and are coeval to slightly younger to emplacement of large granitoid plutons (Leube et al., 1990; Cheilletz et al., 1994; Pons et al., 1995). These Birimian terranes extend over more than two thirds of the eastern Man shield (Guinea, southern Mali, Ivory Coast, Ghana, Burkina Faso, southwestern Niger and northern Togo), the Kayes (in Mali) and KKI (Milési et al., 1989; Feybesse et al., 2006).

The lithological succession of the Birimian formations is very controversial. Some researchers (Junner, 1935; Milési et al., 1989, 1992; Ledru et al., 1991) proposed a predominantly sedimentary lower Birimian $\left(\mathrm{B}_{1}\right)$, and a volcanic and pyroclastic dominantly upper Birimian $\left(B_{2}\right)$. Lateral equivalents of volcanic and sedimentary rock sequences were also envisaged (e.g. Leube et al. 1990; Hirdes et al. 1992). Recent radiometric dating of the volcanic and sedimentary units (Davis et al., 1994; Doumbia et al., 1998; Lüdtke et al., 1998, 1999; Dia et al., 1998; Hirdes and Davis, 2002; Théveniaut et al., 2010) places the major period of accretion of juvenile mafic volcanic-plutonic rocks around 2.25-2.17 Ga, whereas the 
102 Birimian sedimentary activity occurred at 2.15-2.10 Ga (Abouchami et al., 1990; Bassot, 103 1997; Feybesse et al., 2006).

104 The Birimian formations were deformed during the 2.1-2.0 Ga Eburnean orogeny 105 (Bonhomme, 1962; Abouchami et al., 1990; Liégeois et al., 1991; Boher et al., 1992; Taylor 106 et al., 1992). Eburnean tectono-magmatic events are interpreted by some authors as a single 107 progressive deformation event involving compression along a NW-SE axis (Eisenlohr and 108 Hirdes, 1992; Blenkinsop et al., 1994). For others, the evolution is polycyclic including three 109 major phases of deformation: $\mathrm{D}_{1}$, collisional (Ledru et al., 1989, 1991; Milési et al., 1992), 110 peri-plutonic deformations (Vidal et al., 1996; Pouclet et al., 1996) or vertical tectonics of 111 unconstrained side diapirs (Vidal et al., 2009; Lompo, 2010), and $\mathrm{D}_{2}$ and $\mathrm{D}_{3}$ transcurrent 112 faulting (Milési et al., 1989; Feybesse et al., 1989; Dabo and Aïfa, 2011). The metamorphism 113 related to the Eburnean orogeny in the Birimian formations of the WAC is of mesozonal 114 facies (Klemd et al., 2002; Block et al., 2015) before being locally overprinted by epizonal 115 facies (Dia, 1998; Debat et al., 2003; Block et al., 2015). Eburnean deformation features host 116 the majority of the gold deposits, which generally occur aligned along major tectonic zones 117 (Milési et al., 1989, 1992; Liégeois et al., 1991; Feybesse et al., 2006; Dabo et al., 2015).

\section{Geology of Kédougou-Kéniéba Inlier}

120 The Paleoproterozoic Birimian of the KKI consists of volcanic, volcano-sedimentary, and 121 sedimentary formations, which are distributed into two supergroups (Bassot, 1987): the Mako 122 Supergroup to the west and the Dialé-Daléma Supergroup in the east, separated by a crustal123 scale shear zone, the Main Transcurrent Zone (MTZ) (Fig. 1b).

124 The Mako Supergroup is composed of bimodal volcanoplutonic sequences (Ngom, 1995; Dia et al., 1997) with ultramafic bodies associated with submarine volcanism at the bottom and andesitic flows with abundant pyroclastites and volcano-detrital rocks at the upper parts of the

\section{7 pile.}

128 The bimodal volcanic belts consist successively of tholeiitic and calc-alkaline rocks (Dia, 1988; Ngom, 1995). The tholeiitic sequences at the bottom of these belts are mainly

130 represented by pillow basalts and/or none structured basaltic flows with N- or T-MORB 131 affinities and large slices of ultramafic-mafic rocks (Dia et al., 1997; Delor et al., 2010). The mafic rocks (metabasalts and metagabbros) and the ultramafic rocks exhibit comagmatic geochemical and lithological features (Ngom, 1995). The calc-alkaline volcanism is

134 composed of andesitic to felsic rocks with abundant pyroclastics interstratified with volcanodetrital material (Diallo, 1994; Ngom, 1995; Dia et al., 1997). 
136 The volcanic assemblage is dated between 2170 and $2213 \pm 3$ Ma (Abouchami et al., 1990,

137 Dia et al., 1997; Gueye et al., 2007). The volcanic packages and the granitoids are interpreted

138 to have island arc affinities on the basis of geochemical and petrological constraints (Dia, 139 1988; Diallo et al., 1993; Diallo, 1994; Dia et al., 1997; Pawlig et al., 2006) or represent 140 mantle plume assemblageultramafic-mafic rocks followed by orogenic volcanic arc 141 assemblages for the calc-alkaline complex (Bassot, 1987; Abouchami et al., 1990; Hirdes et 142 Davis, 2002; Ngom et al., 2010).

144 The Dialé-Daléma Supergroup, in contrast with the Mako Supergroup, is composed primarily of turbiditic and carbonated metasediments, and is cross-cut by volcanic complex, which is mainly made up of andesitic and rhyolitic rocks (Milési et al., 1986, 1989; Dommanget et al., 1993; Dabo and Aïfa, 2010).

148 Detrital sedimentary rocks of Dialé-Daléma in the Loulo district have been dated between $1492098 \pm 11 \mathrm{Ma}$ and $2125 \pm 17 \mathrm{Ma}$ (Boher et al., 1992) and detrital zircons from a quartz wacke 150 gave an average age of $2165 \pm 1$ Ma for the source rocks (Hirdes and Davis, 2002). A rhyolite 151 flow Unit from the southern parts of the Dialé-Daléma Supergroup has been dated at $2099 \pm 4$ 152 Ma (Hirdes and Davis, 2002).

153 The Birimian volcanic, volcano-sedimentary and sedimentary rocks of the Mako and Dialé154 Daléma Supergroups are intruded by several generations of Eburnean granitoids, which form 155 three batholiths: Badon-Kakadian, Saraya and Boboti (Bassot, 1966; Dia et al., 1997). The 156 Badon-Kakadian batholith consists of a complex suite of pre- and syn-tectonic mafic to felsic 157 rocks, dated in the range of 2080-2213 Ma (Dia, 1988; Dia et al., 1997; Gueye et al., 2007). 158 The Saraya and Boboti batholiths consist of calc-alkaline syn-tectonic I-type, hornblende159 biotite-bearing TTG granitoids with ages ranging between 2100-2060 Ma (Saraya) and 20801602060 Ma (Boboti) (Hirdes and Davis, 2002; Gueye et al., 2007; Delor et al., 2010). 161 Théveniaut et al. (2010) assembled these batholiths into three suites: Sandikounda-Soukouta 162 (2170-2140 Ma), Saraya (2100-2060 Ma) and Boboti (2080-2060 Ma).

163 The metamorphism of Birimian formations of the KKI is mostly in the greenschist facies, but 164 amphibolite facies can be found locally, such as in the Sonfara-Sandikounda amphiboliticgneissic complex and around some plutons (Bassot, 1966; Dia et al., 1997).

166 Structural studies distinguish generally three major phases of Eburnean deformation $\left(\mathrm{D}_{1}, \mathrm{D}_{2}\right.$ 167 and $\mathrm{D}_{3}$ ) in the KKI (Ledru et al., 1989, 1991; Dabo and Aïfa, 2011): $\mathrm{D}_{1}$ of compressional 168 tectonics (thrusting), $\mathrm{D}_{2}$ transcurrent or transpression tectonics with NS to NE-SW sinistral 169 strike-slip faults and $\mathrm{D}_{3}$ dextral transcurrent or transtension tectonics. $\mathrm{D}_{2}$ is associated with 
170 two large NS- to NE-trending tectonic contacts: the Senegalo-Malian Fault (SMF) in the 171 Dialé-Daléma Supergroup (Bassot and Dommanget, 1986; Bassot 1987; Dabo, 2011) and the

172 MTZ, which marks the limit between both the Mako and Dialé-Daléma Supergroups (Fig. $1731 b)$.

174 This paper is a contribution to the lithostratigraphic and geodynamic debate on the KKI 175 Birimian terranes. The results presented below bring new field and petrographic data which 176 requires a reconsideration of the existing lithologic and geodynamic models suggested for the 177 Mako Supergroup.

\section{Lithological architecture of Mako}

180 The Mako Sector, in the northern part of Mako Supergroup (Fig. 1b), is a metamorphic assemblage zone primarily made up of ultramafic, mafic, intermediate and felsic rocks associated with quartzites (Fig. 2a). Mafic rocks are the most significant and constitute the main part of the greenstone hills between Seguéko Fulani to the north and Wassadou to the south. Beside the hills made up of greenstone belt mafic rocks also exposed are black ultramafic rocks of Koulountou and of Manssari-Tana forming topographic highs, to the east and west of Mako village, respectively. Kilometric lenses of quarzites, oriented NW-SE and NE-SW, are inserted locally between the mafic rocks. Andesitic breccias and felsic lavas occupy the tectonic corridors cross-cutting the ultramafic, mafic and quartzites rocks. All these formations are cross-cut by several generations of plutons (granitoids and gabbros) which constitute the main part of the outcrops in Niéméniké village (Fig. 2). On the EW cross-section, between Lamé and Badian villages (Fig. 2b), ultramafic rocks, layered gabbros, pegmatitic gabbros and isotropic gabbros follow one another gradually with a sharp regular subvertical contacts. In the tectonic corridor of Bafoundou, the gabbros are cross-cut by red andesitic breccias which pass laterally to quarzites then to pillow basalts in the neighbourhoods of the Badian village. The contact between ultramafic rocks, gabbros and basalts is progressive. On the other hand, fault contacts separate the ultramafic-mafic rocks from the andesitic breccias and quarzites. On the NW-SE cross-section (Fig. 2c), between

198 Lamé and Sékhoto Peul, a lithologic succession, almost similar to that of the previous section is exposed. However, the andesitic breccias give way to rhyolitic breccias and rhyolitic lavas of the Mako Supergroup which cross-cut the metabasalts. These metabasalts, often appear as 201 pillow lavas, are common towards Sékhoto Peul. In addition, several generations of plutonic intrusions (granitoids and gabbros) with variable tectonic fabrics, were emplaced into the

203 volcanic and volcano-sedimentary units between Niéméniké and Sékhoto Peul (Fig. 2). 
204 The space distribution and the geometrical relations between the various lithological facies,

205 enable us to distinguish two lithological units: the ophiolitic complex at the base and the mixed volcanic complex at the top, separated by the lenses of quarzites.

\section{1. The Mako Ophiolitic Complex}

209 The Mako Ophiolitic Complex (MOC) consists of partially serpentinized ultramafic rocks 210 associated with metagabbros, amphibole-gneiss, massive and pillow metabasalts and the 211 overlying quarzites.

\section{Ultramafic rocks}

214 Ultramafic rocks outcrop in the hills of Koulountou and of Manssari-Tana (Fig. 3a), in the 215 shape of polygonal blocks and boulders of variable sizes. The rock surface is red to ochre in 216 colour and exhibits severe alteration (Fig. 3b). On a fresh surface, it has a fine grained texture; 217 balck with phenocrysts of pyroxenes associated with some greenish olivine grains. The 218 olivines are alterated to a whitish crust of serpentine (Fig. 3b).

219 Under the microscope, the rocks comprise metaperoditites (wehrlites and lherzolites) and metapyroxenites (websterites). The lherzolites show an abundance of olivines and pyroxenes set in a heteradcumulate texture (Fig. 3c). Magnesian olivines and orthopyroxenes are often altered into serpentine and opaque minerals. Clinopyroxenes are partly transformed into amphibole (actinote), chlorite and calcite. Some chromite crystals appear locally. The wehrlites are characterized by clinopyroxenes which occupy the interstices between the cracked olivine crystals. In the cracks also occur recrystallized serpentine and opaque minerals.

Pyroxenites are mainly websterites, which are mostly composed of both orho- and clinoclinopyroxenes and opaque minerals. The clinopyroxenes are generally transformed into amphibole, chlorite and calcite. These metapyroxenites as well as some metagabbros result from the differentiation by fractionated crystallization of the ultramafic magma (Ngom, 231 1995).

\section{Metagabbros and amphibole-gneisses}

234 Metagabbros often crop out at the base of the hills of metabasalts and are associated with 235 ultramafic rocks towards the top and laterally (Fig. 3a). They are almost confined between the 236 hills of ultramafic rocks with metagabbros to the east and the metabasalts to the west of 237 Mako. They have several equant (isotropic), pegmatitic with comb-layered textures (Lofgren 
and Donaldson, 1975; Figs. 3d,e). The isotropic metagabbros are more abundant and crop out mainly in the centre and west of Mako. They are characterized by a coarse grained texture with grains of amphibole, pyroxene, chlorite, plagioclase, quartz and opaque minerals (Fig. 3d). The coarse grained pegmatitic grabbros are more abundant towards the SE. They often show a comb-layered texture (Lofgren and Donaldson, 1975) with phenocrysts of clinopyroxene arranged in sheaves (Fig. 3e) leaving meshs occupied by plagioclases and secondary minerals (quartz, epidote, calcite and opaque minerals). These pegmatitic gabbros are a result of the differentiation of websterites and are marked by the increase in the modal composition of oxides and the increase in the size of minerals in the rock (Ngom, 1995).

In the SE part (towards Lamé) hectometric massifs of layered metagabbros conformably outcrop on the ultramafics and the pegmatitic gabbros (Fig. 3f). Under polarizing microscope they appear like amphibole-gneisses with granolepidoblastic texture, characterized by an alternation of light feldspathic minerals and ferromagnesian minerals (mainly pyroxenes, amphiboles and chlorites) (Fig. 3g). Plagioclases represent the main part of light minerals and are sometimes transformed into calcite, epidote and quartz. Quartz occurs in the form of microcrystals dispersed in the interstices between other minerals. In the mafic units, the amphiboles are more abundant and consist mainly of secondary hornblende and actinolite. They are sometimes transformed into layers of chlorite adjacent to the amphibole needles. Clinopyroxenes, partially transformed into amphibole and calcite, are disseminated in the background of the thin section. Rare orthopyroxenes and olivines partially altered into serpentine, appear in the ferromagnesian mineral. Some grains of epidote, sphene and needles of damourite supplement the mineralogy of these amphibole-gneisses. These amphibolegneisses described for the first time in the Mako Sector, testify an amphibolite degree of metamorphism. The metagabbros pass in general gradually to metabasalts at the top with hardly discernible diffuse limits even sometimes of interpenetrations between both facies

\section{4 (Fig. 3d).}

\section{Metabasalts}

267 The metabasalts occupy mainly the top of the hills of greenstone rocks bordering the Mako 268 village (Figs. 2,3a). On the front wall of the quarry of the Sahelian Enterprises Co., the metagabbros pass gradually into massive metabasalts then in pillow basalts at the top (Figs. 4a,b). These pillow lavas locally contain black enclaves of metaperidotites (Fig. 4c) made up of layered serpentines associated with some secondary calcite crystals and opaque minerals 
(Fig. 4e). Massive metabasalts, often with amygdalae structures (Figs. 3d,4), outcrop mainly in the eastern part of Mako village where they are found on top of the metagabbros in some areas. The rock has a microlithic texture with a chloritized mesostase which appear as plagioclase microliths associated with rare secondary quartz grains and pyroxene relics (Fig. 4d,e). The amygdalae locally abundant comprises elliptical vesicles filled up with hydrothermal paragenesis with quartz, feldspar, chlorite, epidote (Fig. 4d).

The more frequent metabasalts in the hills of the western part of Mako show pillows (Figs. $4 a, b)$ of variable size ranging from centimetric to metric. The pillow basalts generally sit on top of or are interstratified with the massive metabasalts (Figs. 4d,e). In the pillow metabasalts appear ribboned tension gashes which are partially filled up by the same paragenesis as that of the amygdalas in the massive metabasalts. In the shear zones, the metabasalts are transformed into chloritoschists exhibiting the following secondary mineralogy: chlorite, epidote, feldspar, quartz and opaque minerals (Fig. 4f). The pillow metabasalts are overlain locally by lenses of ribboned quarzites.

\section{Quartzites}

289 The quarzites form hills defined by lenticular beds that are stretched and "boudinaged" within 290 the mafic rocks. The thickness of the beds is variable and exceeds $500 \mathrm{~m}$ in some places. At 291 the outcrop, the primary bedding is defined by an alternation of light and dark centimetric 292 beds (Fig. 5a). The texture is granoblastic, mainly made up of microgranular quartz associated 293 with some sericite needles (Fig. 5b). The light beds are composed of quartz and dark beds of quartz and reddish iron oxides, similar to jasperoids. Locally, conglomeratic quartzites with rare centimetric rollers are also exposed. The rollers are dark and deformed and in thin section are made up of chlorite and sericite (damourite) associated with secondary greyish quartz.

297 The quarzites constitute the sedimentary cover of the metabasalts and metagabbros and represents recrystallized and deformed jaspers with radiolarians. In addition, some $\mathrm{N} 160^{\circ}$ oriented quarzites bands show minor ferromagnesian mineral relics (epidote, chlorite)

\subsection{The Mixed Volcanic Complex}

303 It consists of a mixed volcanism (explosive and effusive) represented by breccias and 304 andesitic, rhyodacitic and rhyolitic lavas, which crop out in tectonic corridors between Mako and Bafoundou villages. These volcanites are injected into the rocks of the MOC (Fig. 2). 


\section{Andesitic breccias and lavas}

308 The andesitic breccias consist of polygenic rock fragments of variable sizes (millimetric to 309 centimetric) and rock type (sedimentary, magmatic) mainly of magmatic origin. These 310 lithoclasts, with subround shapes occur in the shear zones whereas the angular lithoclasts 311 occur outside the shear zone. The lithoclasts are packed in a fresh greenish or reddish brown 312 mesostase (Figs. 6a,b). Grain sorting of the lithoclasts (Fig. 6b) is perceptible at certain places 313 and shows local lithologic inversions due to deformation. They locally show cross-bedding, 314 channelling features characteristics of fluviale deposition (Fig. 6a). In thin section, one can 315 observe microlithic lithoclasts within a cement entirely recrystallized out of quartz, feldspar, 316 chlorite and epidote (Fig. 6c,d). The fine mafic grained enclaves are metagabbroic with 317 crystals of amphibole, clinopyroxene, chlorite and feldspar (Fig. 6b). In spoil of a well dug on 318 the level of a shear zone west of Mako village, the rock is transformed at depth into 319 chloritoschists of porphyritic lepidogranoblastic texture with an alternation of phyllitic beds 320 (with chlorite and sericite) and quartzo-sericitic beds, containing lithoclasts of quarzite, basalt 321 and peridotite (Fig. 4f).

323 The andesitic breccias are interstratified with andesitic lavas which locally constitute 324 sharpened hills in particular to the NW of Mako village. The lavas are distinguished by the 325 presense of plagioclase and amphibole phenocrysts in a greenish mesostase (Fig. 6d). The 326 texture is microlithic porphyritic with plagioclase microliths associated with some opaque 327 minerals in a mesostase strongly recrystallized out of chlorite and epidote. Feldspars form poecilitic phenocrysts of twinned plagioclases and some with Carlsbad twinned sanidines are common.

\section{Breccias and rhyolitic and rhyodacitic lavas}

331 The breccias and andesitic lavas west Mako pass gradually to rhyolitic and rhyodacitic 332 breccias to the east Mako. These rocks are coarser in the west and become increasingly finer 333 towards the east. The contact between the andesitic and rhyolitic breccias seems progressive 334 even though no contact was observed between the two facies. The rhyolitic lavas are abundant close to the pink granite of Niéméniké (Fig. 2). They are interstratified with rhyolitic breccias which show magmatic bedding with an alternation of fine siliceous grains and horizons made up of medium feldspathic grains (Fig. 6e). In the shear zones, they are mylonitized and transformed into sericitoschists (Fig. 6f). Feldspar and quartz coarse grains are packed within 
the foliation. Some red trails of oxide and the feldspathic koalinitization underline major 340 schistosity.

341 In the SE part, the breccias and rhyolitic lavas are associated with breccias and rhyodacitic 342 lavas. They show a porphyritic microlithic texture with feldspar phenocrysts (plagioclase and 343 sanidine) in a mesostase strewn with plagioclase microliths, biotite and chlorite layers, as well 344 as grains of epidote and quartz. The whole of these Birimian ultramafic, mafic, intermediate 345 and felsic formations is cross-cut by the Eburnean granitoid intrusions.

\subsection{Eburnean granitoids}

348 The granitoids of the Mako Sector consist of diorites, granodiorites and granites. They form several generations of massifs with variable dimensions, which are intrusive into the ophiolitic and mixed volcanic complexes (Fig. 2). According to their age, their relationships to the Birimian formations and the Eburnean deformation, three groups of massifs can be distinguished: (i) early granitoids $\pi 1$ (2200 Ma to $2160 \mathrm{Ma}$ ), deformed and intrusive into the greenstone belts; (ii) conformable syn-tectonic granitoids $\pi 2$ (2150 Ma to $2100 \mathrm{Ma}$ ); (iii) and subarounded post-tectonic granitoids $\pi 3$ (2090 Ma to $2040 \mathrm{Ma}$ ). These last two groups are intrusive into the greenstone belts and the sedimentary Birimian basins.

Early Granitoids $\boldsymbol{\pi} \mathbf{1}$ are represented in the Mako Sector by the Soukourtou microgranite with biotite cross-cut by granodiorite with mafic enclaves (Fig. 7a). At the outcrop, the pinkish coloured rock presents a fine granulometry and an intense deformation underlined by a folding and a rough foliation (Fig. 7a). The mineralogy is mainly composed of microcrystals of quartz, feldspar and biotite organized in a microgranular and even granoblastic texture with a rough foliation underlined by the alignment of some partially chloritized biotite layers. Muscovite, epidote and opaque minerals supplement the mineralogy of the rock (Fig. 7b). This microgranite underwent the effect of contact metamorphism related to the emplacement of the granodiorite with mafic enclaves which involved its deformation and its transformation into orthogneiss (Fig. 7a).

367 This granite with orthogneiss biotite would represent a part of the granodiorite of Badon 368 located $\sim 3 \mathrm{~km}$ northward and dated by ${ }^{207} \mathrm{~Pb} /{ }^{206} \mathrm{~Pb}$ method on zircon at $2213 \pm 3 \mathrm{Ma}$ 369 (Gueye et al., 2007). This early plutonism emplaced subsequently to the ophiolitic complex 370 of the Mako Sector. This emplacement occurred during the first phase of Eburnean 371 deformation $\mathrm{D}_{1}$ which involved in pillow basalts a ductile deformation (folding) while the 372 rock was not completely cool. 
Syn-tectonic granitoids $\boldsymbol{\pi} \mathbf{2}$ are the massifs elongated according to NE-SW to NS Eburnean directions and often containing mafic enclaves. They show a planar anisotropy marked by the stretching of quartzo-feldspathic grains according to a foliation underlined by phyllitic minerals. In the study area, they are represented by the granodiorites of Soukourtou (Fig. 7a) and the curve of Sékhoto Peul along the RN7 road as well as mesocrat diorite of Niéméniké (Fig. 2).

The granodiorite of Soukourtou is leucocratic, but locally blended of mafic enclaves which confers it a mesocrat aspect. On its western edge, the granodiorite is injected or in contact with the orthogneissified microgranite. Its contact with the metabasalt is irregular, which assumes a contemporaneous to sub-contemporaneous emplacement. On thin sections, millimeter-length crystals of quartz, alkaline feldspars (orthoclase, microcline), plagioclase and lengthened layers of biotite and amphibole can be distinguished. The leucrocrat granodiorite of the curve of Sékhoto Peul along the RN7 road also presents mafic enclaves. It shows grains of quartz $(\sim 30 \%)$, plagioclase $(\sim 35 \%)$, alkaline feldspar $(\sim 5 \%)$ and layers of biotite $(\sim 12 \%)$ and amphibole $(\sim 10 \%)$ lengthened according to the foliation direction (Fig. 7a). The texture is mainly grained, but locally becomes microgranular, particularly in the vicinity of the enclaves. In the parts rich in enclaves, the rock becomes mesocrat because of the rate increase of ferromagnesian minerals coming from the mafic facies.

The mafic enclaves of the granodiorites are generally deformed (boudinaged, sheared, twisted) with irregular limits (Figs. 7d,e). They are mostly made up of secondary amphiboles $(\sim 65 \%)$ associated with quartz and feldspars (Fig. 7e). Rare relics of olivine and orthopyroxene developing a rim of green alteration with epidote, can be observed. In the granodiorite of Sékhoto Peul, the mafic enclaves are transformed into dark diorite. The limits between minerals of the enclaves and those of the granodiorite are diffuse (Fig. 7d). In some places, minerals of the enclaves are isolated within minerals from the granodiorite and vice versa (Fig. 7f). Moreover, injections of the granodiorite appear in the fractures of the enclaves

\section{9 (Fig. 7d).}

400 In the granodiorite of Sourkoutou the mafic enclaves are metagabbros showing a 401 microgranular rim reaction separating them from the granodiorites (Fig. 7e). These granodiorites with mafic enclaves would be related to an incomplete mixture (mingling) between a mafic magma and the felsic magma with faster cooling of the less viscous mafic magma (Pitcher, 1993; Nédélec and Bouchez, 2011). granodiorite. The rock shows a grained texture made up of centimetric plagioclase and 
407

408

409

410

411

412

413

414

415

416

417

418

419

420

421

422

423

424

425

426

427

428

430

431

432

433

434

435

436

437

438

439

440

amphibole rods, intermingled with some quartz and biotite. It is slightly deformed with a rough anisotropy, tension gashes and fractures. These fractures are secondarily borrowed by primarily feldspathic aplitic arrivals.

In chronological viewpoint, these diorites and granodiorites would be the equivalent of the granodiorite of Soukouta, located at about $5 \mathrm{~km}$ westward, dated by U/Pb on zircon at $2142 \pm$ 7 Ma (Delor et al., 2010).

Post-tectonic granitoids $\boldsymbol{\pi} 3$ form the subarounded massifs with equant texture often without enclaves and unconformable on Eburnean structures. They are represented by the pink granite of Niéméniké, made up mainly of alkaline feldspars such as orthose, associated with bluish quartz and plagioclase. The ferromagnesian minerals are represented by needles of amphibole and mica layers (muscovite and biotite). The deformation is primarily brittle but some small shear corridors appear locally. Pegmatic and aplite dykes and intrusions of spotted grabbros are injected into the rock fractures (Fig. 8a). These post-tectonic granites can be chronologically related to that of Tinkoto located at around $7 \mathrm{~km}$ southward and dated by $\mathrm{U} / \mathrm{Pb}$ method on zircon at $2074 \pm 9 \mathrm{Ma}$ (Gueye et al., 2007).

The late spotted gabbros are dykes and late gabbros massifs, mottled fine needles of pyroxenes ouralitized in amphiboles which draw a dark mineral lineation (Fig. 8a). They outcrop in Niéméniké, and are locally dioritic and cross-cut the quarzites and the late granitoids. The dykes of various sizes and orientations, are localized along the fractures of limited extension. They are locally deformed and are different from the Paleoproterozoic dykes reported on the WAC by Jessel et al. (2015). Under the microscope, from the amphibole layers, pyroxene relics (orthopyroxenes and clinopyroxenes) partially chloritized and epidotized associated with some quartz crystals, feldspars and of opaque minerals are distinguished (Fig. 8b). In the most deformed terms, the rock is connected with foliated dioritic metagabbros. Quartz and feldspar become more abundant and form clear beds with recrystallized fine grains alternating with the dark beds of amphiboles and pyroxenes (Fig. $8 \mathrm{c})$. The texture evolves from grained to nematogranoblastic according to localization or not of the rock in the shear zones (Fig. 8b,c).

The age of these mottled gabbros is not yet defined. However, our observations suggest an age younger than that of post-tectonic granitoid they cross-cut (Fig. 8a). The foliation of the mottled gabbros could be related to a late Eburnean deformation phase $\left(D_{3}\right)$ which occurred during the emplacement of these gabbros. The granitoids already exhibit a semi-ductile deformation and occur along a corridor with moderate shearing. The gabbroic dykes are injected into the semi-ductile structures. 
441 Finally, note that the syn- and post-tectonic granitoids appear in the greenstone belt rocks as

442 well as in the Birimian sedimentary basins, contrary to early granitoids which cross-cut only 443 the greenstones. Moreover, the ductile deformation is more important in the syn-tectonic 444 granitoids whereas post-tectonic granitoids are equant with a ductile deformation confined in 445 microcorridor shears.

\section{5. Discussion and conclusions}

447 The Birimian formations of the Mako sector consist of ophiolitic and mixed volcanic 448 complexes showing a bimodal geochemical character (tholeiitic and calc-alkaline), separated 449 by a jasperoid horizon and cross-cut by a series of Eburnean granitoids. The unit is 450 metamorphozed in the amphibolite greenschist facies.

\section{The Mako Ophiolitic Complex}

452 Ultramafic rocks in the Mako Sector are differentiated into wehrlite, lherzolite, websterite, 453 pyroxenite and gabbro with a magmatic bedding related to a fractionated crystallization 454 (Ngom, 1995). They present a tholeiitic affinity and are depleted in REE (Delor al., 2010). 455 Their age is not yet known however they are included in the metabasalts dated by $\mathrm{Sm} / \mathrm{Nd}$ 456 (WR) between $2197 \pm 13 \mathrm{Ma}$ and $2195 \pm 11 \mathrm{Ma}$ (Dia, 1988). Other datings are needed to fix 457 the age of these metabasalts of the Mako Supergroup. Moreover, the granodiorite of Badon dated by ${ }^{207} \mathrm{~Pb} /{ }^{206} \mathrm{~Pb}$ at $2213 \pm 3 \mathrm{Ma}$ (Gueye et al., 2007) intrudes the Mako Birimian greenstone belt, thus predicting an older age for the ultramafic rocks. In the Birimian of Ghana, the age of the ultramafic rocks is supported by the field relations, as well as the 2159 $\pm 4 \mathrm{Ma}$ age of the granitoid intruded into the western flank of the ultramafic-greenstone belt complex (Attoh et al., 2006). These ultramafic rocks at the base of a Birimian ophiolitic fragment of the KKI are considered as the diagnosis of subduction tectonic settings (Peters et al., 1991; Pearce, 2003; Attoh et al., 2006; Dampare et al., 2008).

The ultramafic rocks are topped by metagabbros which form with the metabasalts the main part of the greenstones hills (Fig. 9). The metagabbros have variable textures and often occupy the base of such hills, on top of which metabasalts outcrop. Their geochemistry and age are similar to those of metabasalts with which they would be cogenetic (Ngom et al., 2011).

Amphibole-gneisses result from metamorphism of the metagabbro base. They present a paragenesis to quartz, feldspar, amphibole, chlorite, pyroxene and epidote (Table 2), characteristic of the amphibolite facies. This facies would be related to a prograde metamorphism former to retrograde greenschist metamorphism, following the example of the other Birimian provinces of the WAC (Klemd et al., 2002; Block et al., 2015). They are 
interpreted as the result of an oceanic basaltic crust subduction (Pawlig et al., 2006) and illustrate a transition between Archean and Phanerozoic orogens (Klemd et al., 2002; Block et al., 2015).

In Ghana, the pressure-temperature conditions obtained in the Birimian amphibolite facies are of $500-680^{\circ} \mathrm{C}$ at $4.5-10 \mathrm{Kbars}$ (Klemd et al., 2002; Block et al., 2015). This amphibolite facies metamorphism is followed by retrograde greenschist-facies conditions at temperatures of 400$540^{\circ} \mathrm{C}$ associated with hydrothermal alteration and gold mineralization (Klemd et al., 2002).

The age of the Mako amphibolites is not defined, however, the old zircons obtained on the tonalitic gneiss from Sandikounda are dated at $2194 \pm 4$ Ma (Gueye et al., 2007). In Ghana, the $\mathrm{U}-\mathrm{Pb}$ ages on monazite obtained on the amphibolite metamorphism are estimated between $2138 \pm 7 \mathrm{Ma}$ and $2130 \pm 7 \mathrm{Ma}$ (Block et al., 2015).

In addition, in the Mako Sector, the gradient of metamorphism locally varies from SE towards NW, passing from the amphibolite facies to greenschist facies. In the shear zones, the metamorphic conditions are more pronounced.

The metabasalts in pillow lavas are directly topped by massive metabasalts (Figs. 4a,9). These two types of metabasalts would be comagmatic (Ngom, 1995), and show a lithological continuity and a narrow space association in the field. Both let appear a tholeiitic geochemical affinity with however slightly an enrichment in elements, strongly hygromagmaphiles and LREE for massive basalts (Ngom, 1989; Ngom et al., 2011).

The origin of the enrichment of massive basalts in elements strongly hygromagmaphiles and LREE is discussed. It could be related to post-magmatic contaminations (hydrothermalism, metamorphism, deformation) in particular with the intense hydrothermalism associated with the penetrative amygdalae structures (Fig. 3d). For Pawlig et al. (2006), the plumes could be responsible for the partially enriched character of the tholeiitic basalts.

In former research works, the metabasalts in pillow lavas and the metagabbros (depleted tholeiites) are comparable with N-MORB or oceanic plateau basalts (Dia 1988; Abouchami et al., 1990; Ngom, 1995; Théveniaut et al., 2010; Ngom et al., 2011), whereas the massive metabasalts (enriched tholeiites) are comparable with the arc (Ngom, 1989). However, in the $\mathrm{TiO}_{2} / \mathrm{Fe}_{2} \mathrm{O}_{3} / \mathrm{MgO}$ diagrams of Miyashiro (1974); Ti/Cr of Pearce (1975) and $\mathrm{Cr} / \mathrm{Y}$ of Pearce et al. (1980), geochemical data obtained on most ultramafic, mafic and intermediate rocks of the Mako Supergroup (Ngom, 1995) are located in the SSZ field (Fig. 10).

Hectometric lenses of jasperoid quarzites which represent old jaspers with radiolarians constitute the sedimentary covers of the ultramafic and mafic rocks (Fig. 5). However, quarzites containing ferromagnesian mineral relics could be associated with a silicification of 
old magmatic rocks. This lithologic succession of ultramafic and mafic rocks with tholeiitic character covered by jasperoid sediments (Fig. 9) is related to a Birimian ophiolitic sequence in the Mako sector following the example of the Birimian ophiolitic sequences of the WAC (Attoh et al., 2006; Pouclet et al., 2006; Dampare et al., 2008). We named it Mako Ophiolitic Complex (MOC). However, the dyke swarm complex often associated with the ophiolites has not been observed neither in the field nor on the aeromagnetic map (Aïfa and Dabo, 2011).

The MOC is cross-cut by faults through which Mixed calc-alkali Volcanic Complex is emplaced. Indeed, the lavas and breccias of meta-andesites, meta-rhyodacites and metarhyolites are interstratified in tectonic corridors open within the MOC (Fig. 2). The breccias and lavas of meta-andesites represented westwards pass towards the east to breccias and to interstratified rhydacitic and rhyolitic lavas. These formations of mixed volcanism slightly show a calc-alkaline affinity weakly to strongly potassic of subduction zones (Dia, 1988; Abouchami et al., 1990; Ngom, 1995; Théveniaut et al., 2010; Ngom et al., 2011). The andesites of the Mako Supergroup gave an Sm/Nd (WR) age of $2160 \pm 16 \mathrm{Ma}$ (Boher, 1991). The Birimian formations were intruded by granitoids classified into three groups: (i) early $\pi 1$, in the greenstone belt rocks between $2215 \mathrm{Ma}$ and $2160 \mathrm{Ma}$, and (ii) conformable syn-tectonic $\pi 2$ and (iii) unconformable post-tectonic $\pi 3$ emplacements in the basins and greestone belt rocks, during the periods 2150-2100 Ma and 2090-2040 Ma, respectively. These different granitoids are mainly in the field of calc-alkaline magmatism of subduction zones (Delor et al., 2010). Late mottled gabbros cross-cut the granitoids (Fig. 8a). These gabbros were emplaced during the last Eburnean deformation phase in zones of weak extension.

All that precedes, let predict that the southernmost part of the Mako Supergroup would consist of at least two distinct magmatic events (tholeiitic and calc-alkaline) following a polycyclic evolution in an SSZ context (Pearce, 2003) as for other Birimian provinces of the WAC (Béziat et al., 2000; Attoh et al., 2006; Dampare et al., 2008; Lompo, 2009).

\section{Acknowledgements}

We would like to thank Babacar Diop (University of Dakar) for the preparation of the thin sections. We are indebted to Prof. O. Saddiqi and an anonymous reviewer for their fruitful remarks which helped improve the manuscript, and to Dr. Mapeo (EiC) for his help in the English polishing. This is an IGCP638-Unesco contribution. 
544

545

546

547

548

549

550

551

552

553

554

555

556

557

558

559

560

561

562

563

564

565

566

567

568

569

570

571

572

573

574

575

\section{References}

Abouchami, W., Boher, M., Michard, A., Albarède, F.N.T., 1990. A Major 2.1 Ga event of mafic magmatism in West Africa: an early stage of crustal accretion. Journal of Geophysical Research, 95, 17605-17629.

Aïfa, T., Dabo, M., 2011. Airborne survey to investigate mineralizations within eastern Senegal. 23rd Colloquium of African Geology, Jan. 8-14, Johannesburg, South Africa, p.3 (Abstr. vol. Suppl.).

Ama Salah, I., Liégeois, J.P., Pouclet, A., 1996. Evolution d'un arc insulaire océanique birimien précoce au Liptako nigérien (Sirba): géologie, géochronologie et géochimie. Journal of African Earth Sciences, 22, 235-254.

Attoh, K., Evans, M.J., Bickford, M.E., 2006. Geochemistry of ultramafic - rodingite rock association in the Paleoproterozoic Dixcove greenstone belt, southwestern Ghana. Journal of African Earth Sciences, 45, 333-346.

Bassot, J.P., 1966. Etude géologique du Sénégal oriental et de ses confins guinéo-maliens. Mémoires BRGM, 40, 1-332.

Bassot, J.P., 1987. Le complexe volcano-plutonique calco-alcalin de la rivière Daléma (Est Sénégal): discussion de sa signification géodynamique dans le cadre de l'orogénie éburnéenne (Protérozoïque inférieur). Journal of African Earth Sciences, 6(1), 109-115.

Bassot, J.P., 1997. Albitisations dans le Paléoprotérozoïque de l'Est Sénégal : relations avec les minéralisations ferrifères de la rive gauche de la Falémé. Journal of African Earth Sciences, 25(3), 353-367.

Bassot, J.P., Caen-Vachette, M., 1984. Données géochronologiques et géochimiques nouvelles sur les granitoïdes de l'Est du Sénégal. Implication sur l'histoire géologique du Birimien dans cette région. In: Klerkx, J., Michot, J. (Eds.), Géologie Africaine. Tervuren, Belgique, 191-209.

Bassot, J.P., Dommanget, A., 1986. Mise en évidence d'un accident majeur affectant le Paléoprotérozoïque inférieur des confins sénégalo-maliens. Compte Rendu Académie des Sciences, Paris, 302, 1101-1106.

Béziat, D., Bourges, F., Debat, P., Lompo, M., Martin, F., Tollon, F., 2000. A Palaeoproterozoic ultramafic-mafic assemblage and associated volcanic rocks of the Boromo greenstone belt: Burkina Faso: fractionates originating from island-arc volcanic activity in the West African Craton. Precambrian Research, 101, 25-47. 
Blenkinsop, T.G., Schmidt-Mumm, A., Kumi, R., Sangmor, S., 1994. Structural geology of the Ashanti gold mine, Obuasi, Ghana. Geol. Jahrb., D100, 131-153.

Block, S., Ganne, J., Baratoux, L., Zeh, A., Parra-Avila, L.A., Jessell, M., Ailleres, L., Siebenaller, L., 2015. Petrological and geochronological constraints on lower crust exhumation during Paleoproterozoic (Eburnean) orogeny, NW Ghana, West African Craton. Journal of metamorphic Geology, 33, 463-494.

Boher, M., 1991. Croissance crustale en Afrique de I'Ouest à 2,1 Ga. Apport de la géochimie isotopique. Unpuplished PhD thesis University of Nancy I, France, 180p.

Boher, M., Abouchami, W., Michard, A., Albarède, F., Arndt, N.T., 1992. Crustal growth in West Africa at 2.1 Ga. J. Geophys. Res. 97, 345-369.

Bonhomme, M., 1962. Contribution a l'étude géochronologique de la plate-forme de l'Ouest africain. Géologie Minérale, 5, Thesis, University of Clermont-Ferrand, France, 62p.

Cheilletz, A., Barbey, P., Lama, C., Pons, J., Zimmerman, J.L., Dautel, D., 1994. Age de refroidissement de la crou^ te juvénile birimienne d'Afrique de l'Ouest. Données U-Pb, $\mathrm{Rb}-\mathrm{Sr}$ et $\mathrm{K}-\mathrm{Ar}$ sur les formations a` $2.1 \mathrm{Ga}$ du SW-Niger. C.R. Acad. Sci. Paris, 319, 435-442.

Dabo, M., 2011. Tectonique et minéralisations aurifères dans les formations birimiennes de Frandi-Boboti, boutonnière de Kédougou-Kéniéba, Sénégal. PhD Thesis, University of Rennes 1, 233p.

Dabo, M., Aïfa, T., 2010. Structural Styles and Tectonic evolution of the Kolia-Boboti sedimentary basin, Kédougou-Kéniéba inlier, eastern Senegal. Comptes Rendus Geoscience, 342, 796-805.

Dabo, M., Aïfa, T., 2011. Late Eburnean deformation in the Kolia-Boboti sedimentary basin, Kédougou-Kéniéba inlier, Sénégal. Journal of African Earth Sciences, 60, 106-116.

Dabo, M., Aïfa, T., Miyouna, T., Diallo, D.A., 2015. Gold mineralization paragenesis to tectonic structures in the Birimian of the eastern Dialé- Daléma Supergroup, KédougouKéniéba Inlier, Senegal, West African Craton. International Geology Review, 58(7), 807825.

Dampare, S.B., Shibata, T., Asiedu, D.K., Osae, S.,Banoeng-Yakubo, B., 2008. Geochemistry of Paleoproterozoic metavolcanic rocks from the southern Ashanti volcanic belt Ghana: petrogenetic and tectonic setting implications. Precambrian Research, 162, 403-423.

Davis, D.W., Hirdes, W., Schaltegger, U., Nunoo, E.A., 1994. U/Pb age constraints on deposition and provenance of Birimian and goldbearing Tarkwaian sediments in Ghana, West Africa. Precambrian Research, 67, 89-107. 
610 Debat, P., Nikiéma, S., Mercier, A., Lompo, M., Béziat, D., Bourges, F., Roddaz, M., Salvi,

611 S., Tollon, F., Wenmenga, U., 2003. A new metamorphic constraint for the Eburnean orogeny from Paleoproterozoic formations of the Man shield (Aribinda and Tampelga countries, Burkina Faso). Precambrian Research, 123, 47-65.

614 Delor, C., Couëffé, R., Goujou, J.C., Diallo, D.P., Théveniaut, H., Fullgraf, T., Ndiaye, P.M., Dioh, E., Blein O., Barry, T.M.M., Cocherie, A., Le Métour, J., Martelet, G., Sergeev, S., Wemmer, K., 2010. Notice explicative de la carte géologique à 1/200 000 du Sénégal, feuille Saraya-Kédougou Est. Ministère des Mines, de l'Industrie, de l'Agro-Industrie et des PME, Direction des Mines et de la Géologie, Dakar.

Dia, A., 1988. Caractère et signification des complexes magmatiques et métamorphiques du secteur de Sandikounda-Laminia (Nord de la boutonnière de Kédougou, Est du Sénégal): un modèle géodynamique du Birimien de l'Afrique de l'Ouest. Thèse Université Dakar, Sénégal, 350p.

Dia, A., van Schmus, W.R., Kröner, A., 1997. Isotopic constraints on the age and formation of a Palaeoproterozoic volcanic arc complex in the Kedougou inlier, eastern Senegal, West Africa. J. Journal of African Earth Sciences, 24(3), 197-213.

Diallo, D.P., 1994. Caractérisation, d'une portion de croûte d'age protérozoïque inférieur du craton Ouest africain: Cas de l'encaissant des granitoïdes dans le Supergroupe de Mako (boutonnière de Kédougou) - implications géodynamiques. Thèse Université Cheikh Anta Diop Dakar, Sénégal, 466p.

Diallo, D.P., Debat, P., Rocci, G., Dia, A., Ngom, P.M., Sylla, M., 1993. Pétrographie et géochimie des roches méta-volcano-detritiques et méta-sédimentaires du Protérozoi"que inférieur du Sénégal oriental dans le Supergroupe de Mako (Sénégal, Afrique de I'Ouest): incidences géotectoniques. Publications Occasionnelles CIFEG, 23, 1115.

Diallo, D.P., 2001. Lithostratigraphie du Supergroupe de Mako (Paléoprotérozoïque du Sénégal oriental). Implications géodynamiques. Bulletin de l'Institut Fondamental d'Afrique Noire, Série A, 51(1-2), 33-58.

Dommanget, A., Milési, J.P., Diallo, M., 1993. The Loulo gold and tourmaline-bearing deposit : a polymorph type in the early Proterozoic of Mali (West Africa). Mineral. Deposita, 28, 253-263.

Doumbia, S., Pouclet, A., Kouamelan, A., Peucat, J.J., Vidal, M., Delor, C., 1998. 63. 
Eisenlohr, B.N., Hirdes, W., 1992. The structural development of the early Proterozoic Birimian and Tarkwaian rocks of southwest Ghana, West Africa. Journal of African Earth Sciences, 14, 313-325.

Feybesse, J.L., Milési, J.P., Johan, V., Dommanget, A., Calvez, J.Y., Boher, M., Abouchami, W., 1989. La limite Archéen-Protérozoïque inférieur de l'Afrique de l'Ouest : une zone de chevauchement majeur antérieure à l'accident de Sanssandra: l'exemple des régions d'Odienné et de Touba (Côte d'Ivoire). Compte Rendu Académie des Sciences, Paris, 309, 1847-1853.

Feybesse, J.L., Billa, M., Guerrot, C., Duguey, E., Lescuyer, J.L., Milesi, J.P., Bouchot, V., 2006. The Palaeoproterozoic Ghanaian province: Geodynamic model and ore controls, including regional stress modeling. Precambrian Research, 149, 149-196.

Gueye, M., Siegesmund, S., Wemmer, K., Pawlig, S., Drobe, M., Nolte, N., Layer, P., 2007. New evidences for an early Birimian evolution in the West African Craton: An example from the Kédougou-Kénieba Inlier, Southeast Sénégal. South African Journal of Geology, 110, 511-534.

Gueye, M., Ngom P.M., Diène M., Thiam Y., Siegesmund S., Wemmer K., Pawlig S., 2008. Intrusive rocks tectono-metamorphic evolution of the Mako Palaeoproterozoic belt (Eastern Senegal, West Africa). Journal of African Earth Sciences, 50, 88-110.

Hawkins J.W., 2003. Geology of supra-subduction zones-Implications for the origin of ophiolites. Geological Society of America Special Papers, 2003, 373, 227-268.

Hirdes, W., Davis, D.W., 2002. U-Pb Geochronology of Palaeoproterozoic rocks in the Southern part of the Kedougou-Kéniéba inlier, Senegal, West Africa: evidence for diachronous accretionary development of the eburnean province. Precambrian Research, 118, 83-99.

Hirdes, W., Davis, D.W., Eisenlohr, B.N., 1992. Reassessment of Proterozoic granitoid ages in Ghana on the basis of $\mathrm{U} / \mathrm{Pb}$ zircon and monazite dating. Precambrian Research, 56, 8996.

Hirdes, W., Davis, D.W., Lüdtke, G., Konan, G., 1996. Two generations of Birimian (Palaeoproterozoic) volcanic belts in north-eastern Côte d'Ivoire (West Africa): consequences for the "Birimian controversy". Precambrian Research, 80, 173-191.

Jessell, M., Santoul, J., Baratoux, L., Youbi, N., Ernst, R.E., Metelka, V., Miller, J., Perrouty, S., 2015. An updated map of West African mafic dykes. Journal of African Earth Sciences, 112(B), 440-450.

Junner, N.R., 1935. Gold in the Gold coast. Gold Gost Geol. Surv., Accra, Mém., 4, 52p. 
Klemd, R., Hünken, U., Olesch, M., 2002. Metamorphism of the country rocks hosting goldsulfide-bearing quartz veins in the Palaeoproterozoic southern Kibi-Winneba belt (SEGhana). Journal of African Earth Science, 35, 199-211.

Kretz, R., 1983. Symbols of rock-forming minerals. American Mineralogist, 68, 277-279.

Ledru, P., Pons, J., Feybesse, J.L., Dommanget, A., Johan, V., Diallo, M., Vinchon, C., 1989. Tectonique transcurrente et évolution polycyclique dans le Birimien, Protérozoïque inférieur du Sénégal-Mali (Afrique de l'Ouest). Comptes Rendus Académie des Sciences, Paris, 308, 117-122.

Ledru, P., Pons, J., Milési, J.P., Feybesse, J.L., Johan, V., 1991. Transcurrent tectonics and polycyclic evolution in the lower Proterozoic of Senegal-Mali. Precambrian Research, 50, 337-354.

Leube, A., Hirdes, W., Mauer, R., Kesse, G.O., 1990. The Early Proterozoic Birimian Supergroup of Ghana and some aspects of its associated gold mineralization. Precambrian Research, 46, 139-165.

Liégeois, J.P., Claessens, W., Camara, D., Klerkx, J., 1991.Short-lived Eburnian orogeny in southern Mali. Geology, tectonics, $\mathrm{U}-\mathrm{Pb}$ and $\mathrm{Rb}-\mathrm{Sr}$ geochronology. Precambrian Research, 50, 111-136.

Lofgren, G.E., Donaldson, C.H., 1975. Curved branching crystals and differenciation in Comb-Layered Rocks. Contribution Mineral Petrol., 48, 309-319.

Loh, G., Hirdes, W., 1999. Explanatory notes for the geological map of Southwest Ghana 1: 100 000: Sekondi (0402A) and Axim (0403B) sheets. Geol. Jb. B., 93, 149.

Lompo, M., 2009. Geodynamic evolution of the 2.25-2.0 Ga Palaeoproterozoic magmatic rocks in the Man-Leo Shield of the West African Craton. A model of subsidence of an oceanic plateau (Eds.). Paleoproterozoic Supercontinents and Global Evolution. Geological Society of London, Special Publications, 323, 231-254.

Lompo, M., 2010. Palaeoproterozoic structural evolution of the Man-Leo Shield (West Africa). Key structures for vertical to transcurrent tectonics. Journal of African Earth Sciences, 58, 19-36.

Lüdtke, G., Hirdes, W., Konan, G., Koné, Y., Yao, C., Diarra, S., Zamblé, Z., 1998. Géologie de la région Haute Comoé Nord-feuilles Kong ( $4 \mathrm{~b}$ et $4 \mathrm{~d}$ ) et Téhini-Bouna (3a à $3 \mathrm{~d}$ ). Direction de la Géologie Abidjan Bulletin, 178p.

Lüdtke, G., Hirdes, W., Konan, G., Koné, Y., N'da, D., Traoré, Y., Zamblé, Z., 1999. Géologie de la région Haute Comoé Sud-feuilles Dabakala (2b, d et 4b, d). Direction de la Géologie Abidjan Bulletin, 176p. 
Milési, J.P., Diallo, M., Feybesse, J.L., Keita, F., Ledru, P., Vinchon, C., Dommanget, A., 1986. Caractérisation lithostructurale de deux ensembles successifs dans les séries birrimiennes de la boutonnière de Kédougou (Mali-Sénégal) et du Niandan (Guinée); implications giafilogéniques. Publication CIFEG, 1986/10, les formations birimiennes de l'Afrique de l'Ouest, 113-121.

Milési, J.P., Feybesse, J.L., Ledru, P., Dommanget, A., Quedraogo, M.F., Marcoux, E., Prost, A., Vinchon, C., Sylvain, J.P., Johan, V., Tegyey, M., Calvez, J.Y., Lagny, P., 1989. Les minéralisations aurifères de l'Afrique de l'Ouest. Leurs relations avec l'évolution lithostructurale au Protérozoïque inférieur. Chronique Recherche Minière, 497, 3-98.

Milési, J.P, Ledru, P., Feybesse, J.L., Dommanget, A., Marcoux, E., 1992. Early Proterozoic ore deposits and tectonics of the Birimian orogenic belt, West Africa. Precambrian Research, 58, 305-344.

Miyashiro, A., 1974. Volcanic rock series in island arcs and active continental margins. American Journal of Science, 274, 321-355.

Nédélec, A., Bouchez, J.L., 2011. Pétrologie des granites: Structures, cadre géologique. Licence, Master, Capes, Agrégation. Collection Vuibert, 306p.

Ngom, P.M., 1995. Caractérisation de la croûte birimienne dans les parties centrale et méridionale du Supergroupe de Mako. Implications géochimiques et pétrogénétiques. Thèse de Doctorat d'Etat, Université Ch. A. Diop de Dakar, Sénégal, 240p.

Ngom, P.M., 1989. Caractères géochimiques des formations Birimiennes du supergroupe de Mako (Sabodala et ses environs). Journal of African Earth Sciences, 8, 91-97.

Ngom, P.M., Cordani, U.G., Teixeira, W., Janasi, V.D.A., 2010. Sr and $\mathrm{Nd}$ isotopic geochemistry of the early ultramafic-mafic rocks of the Mako bimodal volcanic belt of the Kedougou-Kenieba inlier (Senegal). Arabian Journal of Geosciences, 3, 49-57.

Ngom, P.M., Cissokho, S., Gueye, M., Joron, J.L., 2011. Diversité du volcanisme et évolution géodynamique au Paléoprotérozoïque: exemple du Birimien de la boutonnière de Kédougou-Kéniéba (Sénégal). Africa Geoscience Review, 18(1), 1-22.

Pawlig, S., Gueye, M., Klischies, R., Schwarz, S., Wemmer, K., Siegesmund, S., 2006. Geochemical and Sr-Nd isotopic data on Birimian formations of the Kédougou-Kénieba Inlier (Eastern Senegal): Implications on the Paleoproterozoic evolution of the West African Craton. South African Journal of Geology, 109, 407-423.

Pearce, J.A., 1975, Basalt geochemistry used to investigate past tectonic environments on Cyprus. Tectonophysics, 25, 4167. 
Pearce, J.A., 1980, Geochemical evidence for the genesis and eruptive setting of lavas from Tethyan ophiolites. In Panayiotou, A. (ed.), Ophiolites: Proceedings, International Ophiolite Symposium, 1979: Nicosia, Cyprus, Geological Survey Department, 261-272.

Pearce, J.A., 2003. Supra-subduction zone ophiolites: The search for modern analogues. Geological Society of America Special Papers, 373, 269-293.

Peters, T., Nicolas, A., Coleman, R.G., 1991. Ophiolite Genesis and Evolution of the Oceanic Lithosphere. Kluwer Academic Publishers, Boston, 903p.

Pitcher, W.S., 1993. The nature and origin of granite. Blackie, London, 322p.

Pons, J., Oudin, C., Valéro, J., 1992. Kinematics of large syn-orogenic intrusions: example of the lower Proterozoic Saraya batholith (eastern Senegal). Geologische Rundschau, 81(2), 473-486.

Pons, J., Barbey, P., Dupuis, D., Léger, J.M., 1995. Mechanism of pluton emplacement and structural evolution of $2.1 \mathrm{Ga}$ juvenile continental crust: the Birimian of south-western Niger. Precambrian Res., 70, 281-301.

Pouclet, A., Vidal, M., Delor, C., Simeon, Y., Alric, G., 1996. Le volcanisme birimien du nord-est de la Côte d'Ivoire, mise en évidence de deux phases volcano-tectoniques distinctes dans l'évolution géodynamique du Paléoprotérozoïque. Bulletin de la Société géologique de France, 167(4), 529-541.

Pouclet, A., Doumbia, S., Vidal, M., 2006. Geodynamic setting of Birimian volcanism in central Ivory Coast (western Africa) and its place in the Paleoproterozoic evolution of the man Shield. Bulletin de la Société géologique de France, 177(2), 105-121.

Sylvester, P.J., Attoh, K., 1992. Lithostratigraphy and composition of 2.1 Ga greenstone belts of the West African craton and their bearing on crustal evolution and the ArcheanProterozoic boundary. Journal of Geology, 100, 377-393.

Taylor, P.N., Moorbath, S., Leube, A., Hirdes, W., 1988. Geochronology and crustal evolution of early Proterozoic granite-greenstone terrains in Ghana/West Africa. Abstr. Int. Conf. Workshop, Geology of Ghana with Special Emphasis on Gold, Accra, 43-45.

Taylor, P.N., Moorbath, S., Leube, A., Hirdes, W., 1992. Early Proterozoic crustal evolution in the Birimian of Ghana: constraints from geochronology and isotope geology. Precambrian Research, 56, 97-111.

Théveniaut, H., Ndiaye, P.M., Buscail, F., Couëffé, R., Delor, C., Fullgraf, T., Goujou, J.C., 2010. Notice explicative de la carte géologique du Sénégal oriental à 1/500 000. Ministère des Mines, de l'Industrie, de l'Agro-Industrie et des PME, Direction des Mines et de la Géologie, Dakar, 120p. 
Vidal, M., Delor, C., Pouclet, A., Siméon, Y., Alric, G., 1996. Evolution géodynamique de l'Afrique de l'Ouest entre 2,2 Ga et $2 \mathrm{Ga}$ : le style "archéen" des ceintures vertes et des ensembles sédimentaires birimiens du nord-est de la Côte d'Ivoire. Bulletin de la Société géologique de France, 167(3), 307-319.

Vidal, M., Gumiaux, C., Cagnard, F., Pouclet, A., Ouattara, G., Pichon, M., 2009. Evolution of a Palaeoproterozoic "weak type" orogeny in the West African Craton (Ivory Coast). Tectonophysics, 477, 145-159.

Whitney, D.L., Evans, B.W., 2010. Abbreviations for names of rock-forming minerals. American Mineralogist, 95, 185-187.

\section{Table captions}

Table 1. Previous geochronological data in Mako Supergroup.

Table 2. Mineral assemblages of amphibolites and chloritoschists of Mako.

\section{Figure captions}

Figure 1. Kédougou-Kéniéba Inlier (KKI) in the Man shield, southern part of the West African Craton (WAC). a- Schematic map of the major Precambrian greenstone belts of the southern part of the WAC (simplified from Pouclet et al., 2006). b- Simplified geological map of the Birimian of KKI (modified after Pons et al., 1992). Rectangle delimits the study area. Bo: Boboti; Gm: Gamaye; MTZ: Main Transcurrent Zone; SMF: Senegalo-Malian Fault.

Figure 2. a- Geological map of the Mako Paleoproterozoic greenstone belt. MSZ: Mako Shear Zone; BSZ: Bafoundou Shear Zone. b,c- Geological sections (A-A' and B-B') showing the geometrical relations between different lithologies (the vertical scale is approximative). RN7: trunk road $n^{\circ} 7$.

Figure 3. The ultramafic and mafic rocks of Mako. a- Panoramic view of the hills of ultramafic and mafic rocks. b,c- Petrography of the ultralmafic rocks visible to the naked eye (b) and under polarizing microscope (c). d- Progressive passage by interpenetration between metagabbro and amygdalae metabasalt massif. e- Metagabbro in comb-layered textures showing pyroxene rods ouralitized, arranged in hen foot. f,g- Amphibole-gneiss (layered metagabbro) showing through naked eye (f) and under microscope (g) a foliation with an alternation of light and dark beds. Abbreviations of mineral names according to Witney and Evans (2010). Amp: amphibole, Ep: epidote, Fsp: feldspar, Ol: olivine, Op: opaque mineral, Px: pyroxene, Qz: quartz, Srp: serpentine. 
813 Figure 4. Petrography of mafic rocks of Mako. a- Lithological succession between massive metabasalt and in pillow lavas in a quarry north of Mako. b- Pillow lavas are presented in variable sizes and shapes. c- Basaltic pillow lavas locally contain inclusions of ultramafic rocks. d- Metabasalts showing a microlithic texture with plagioclase microlites whereas (e) inclusions are grained, made up mainly of serpentine (Srp). f- Chloritoschist resulting from the transformation of metabasalts in the shear zone of Bafoundou. Chl: chlorite, Pl: plagioclase.

Figure 5. Ribboned quarzites with an alternation of light and dark beds (a), primarily composed of quartz (Qz) with some sericite (Ser) but locally the conglomeratic quarzites show fragments mainly made up of fibrous chlorite (b).

Figure 6. Volcanic breccias. a- Andesitic breccias showing a cross-bedding $\left(\mathrm{S}_{0}\right)$. b- Andesitic breccias showing a grain sorting with an alternation of fine levels $(\mathrm{Fg})$ and coarse levels (Cg). c- In thin section the fragments show biotite relics. d- Andesitic lava with porphyritic microlithic texture with microliths and phenocrysts of plagioclase bathing in a chloritized mesostase. Alkaline quartz and K-feldspars (Afs) fill amygdalaes of the rock. e- Rhyolitic breccias showing an alternation of Fg and $\mathrm{Cg}$. f- Rhyolite showing a porphyritic microlithic texture with phenocryst of sanidine ( $\mathrm{Sa}$ ) and quartz associated with some biotite $(\mathrm{Bt})$ and sericite (Ser).

Figure 7. Petrography of Eburnean granitoids. a- Granodiorite with mafic enclaves of Soukourtou in contact with the orthogneissified microgranite. b- Contact between granodiorite and microgranite orthogneissified in thin section. c- Mineralogical composition of the Soukourtou granodiorite (Mc: microcline). c- Chilled contact in brown crown between the Soukourtou granodiorite and its mafic enclaves. d,f- Mineralogical hybrid mixture between granodiorite and mafic enclave, observed under naked eye (d) and under microscope (e). Enclaves are crossed by quartzo-feldspathic veinlets (Vn).

Figure 8. a- Mottled metagabbro cross-cutting the post-tectonic pink granite of Niéméniké. bThe metagabbros are mainly composed of secondary amphiboles (Amp) with some chlorite (Chl) and feldspar (Fsp). c- They also cross-cut the quarzite and (d) show an undulated foliation (Fo) by crenulation in certain shear zones.

Figure 9. Schematic lithostratigraphic column of the Paleoprotezoic formations of the Mako sector. complex with calc-alkali trend. The unit is intruded by three generations of granitoid (early, syn- and post-tectonic). The thickness of the facies is estimated approximatively. 
847 Figure 10. Distribution of the volcano-plutonic rocks of Mako in Ti-Cr (a) (Pearce, 1975) and 848 Cr-Y (b) (Pearce, 1980) diagrams, respectively (after data of Ngom, 1995). 


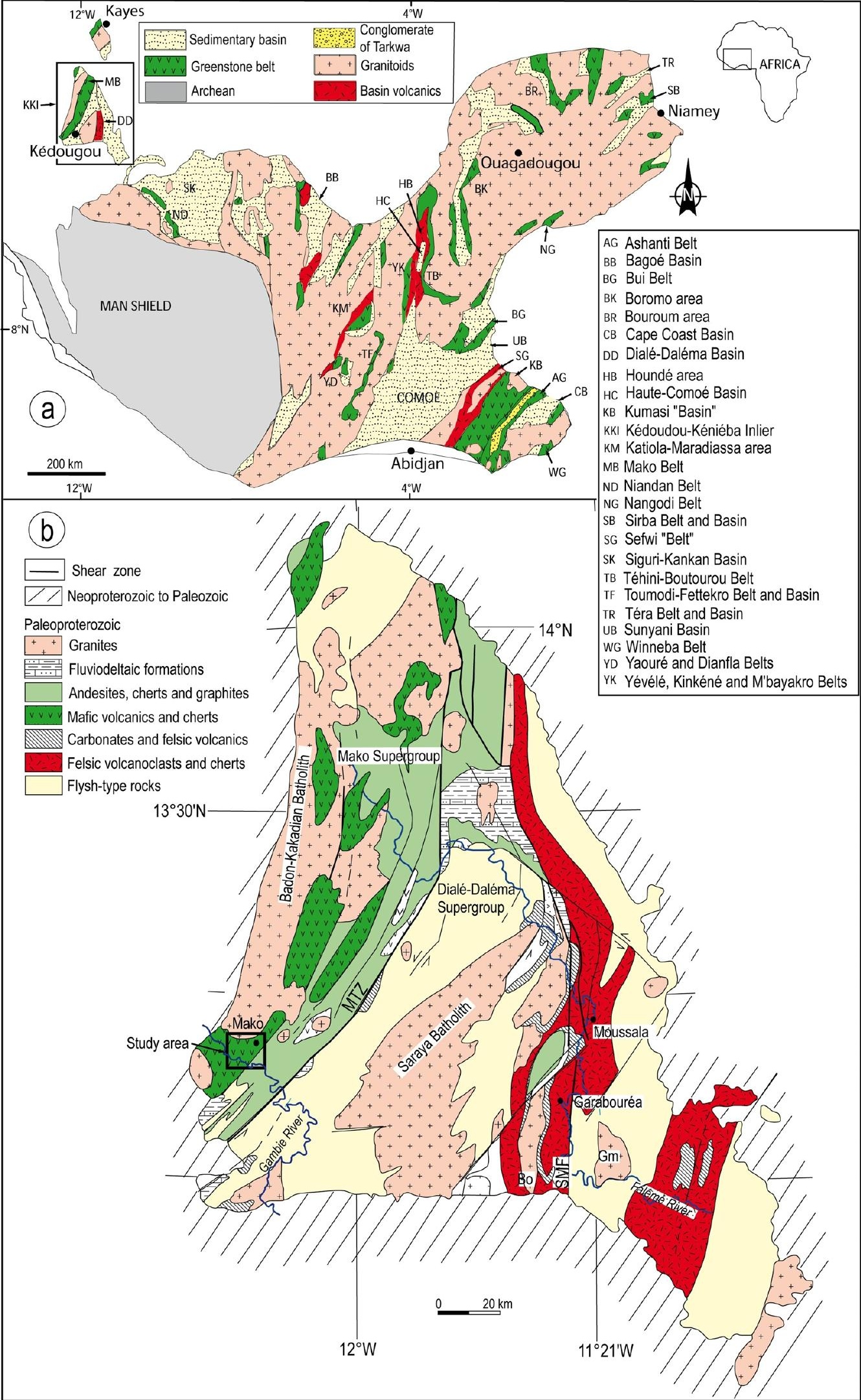



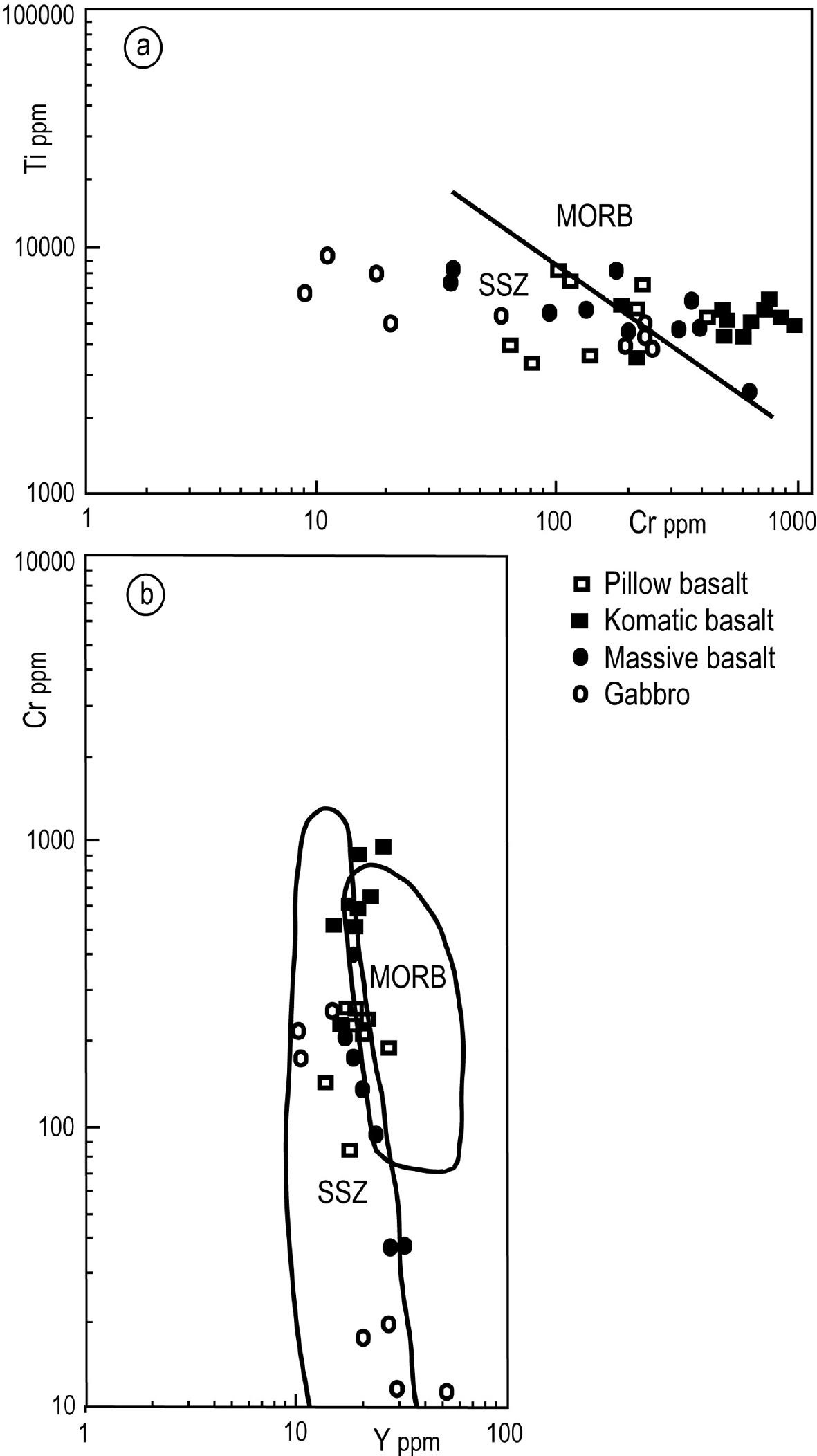


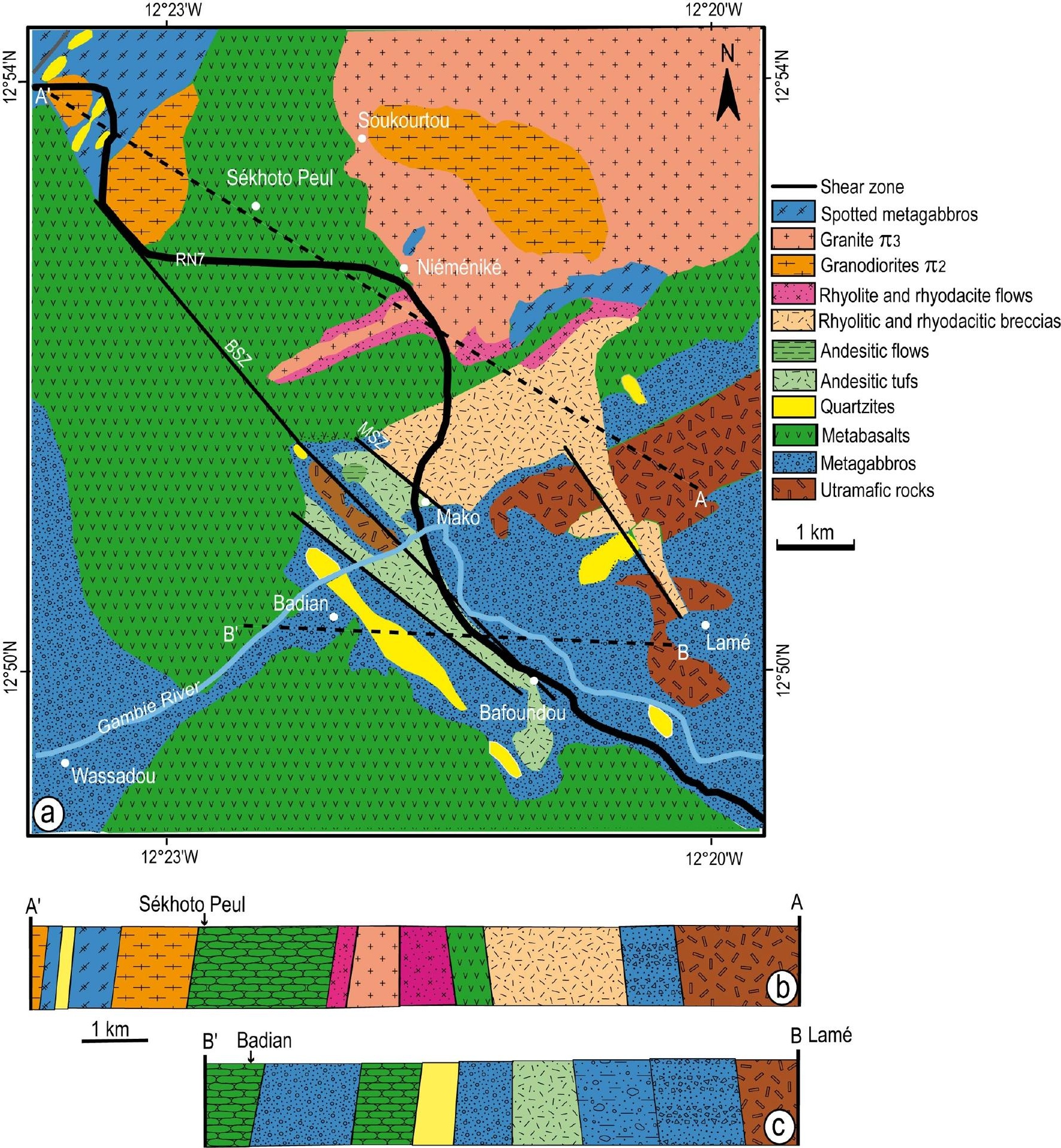



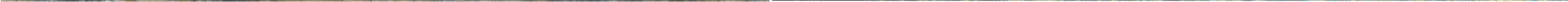


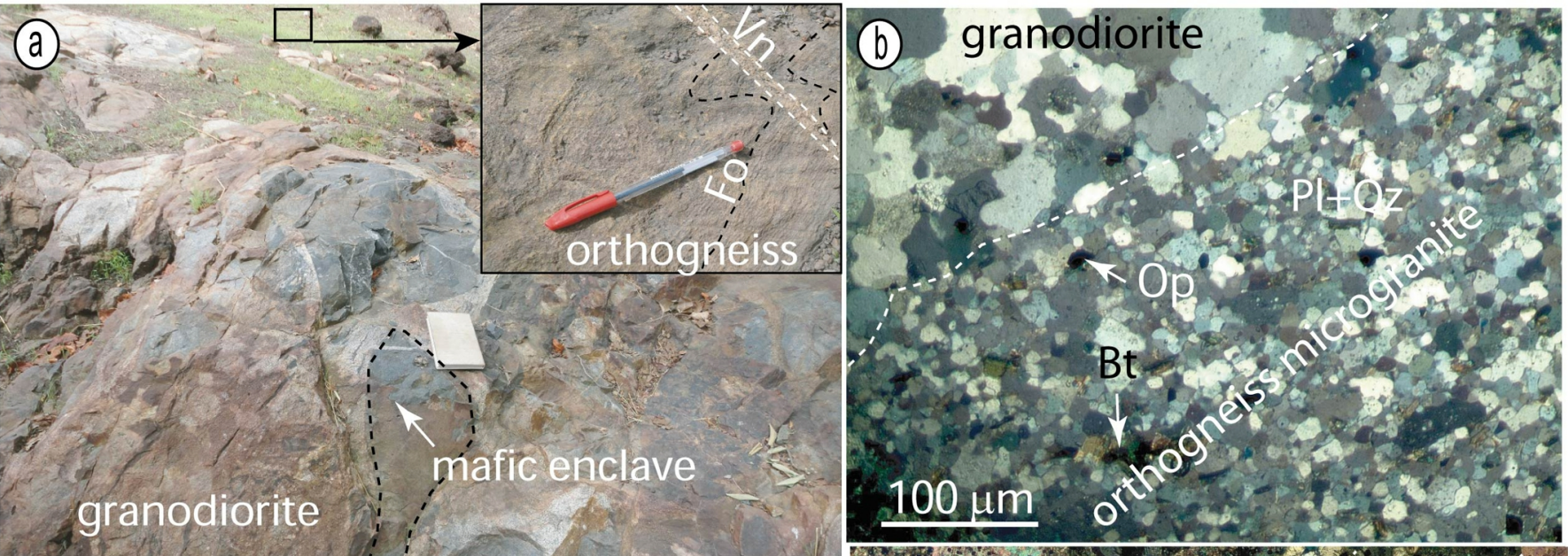


(a) $\quad-$ op

Niéméniké pink granite

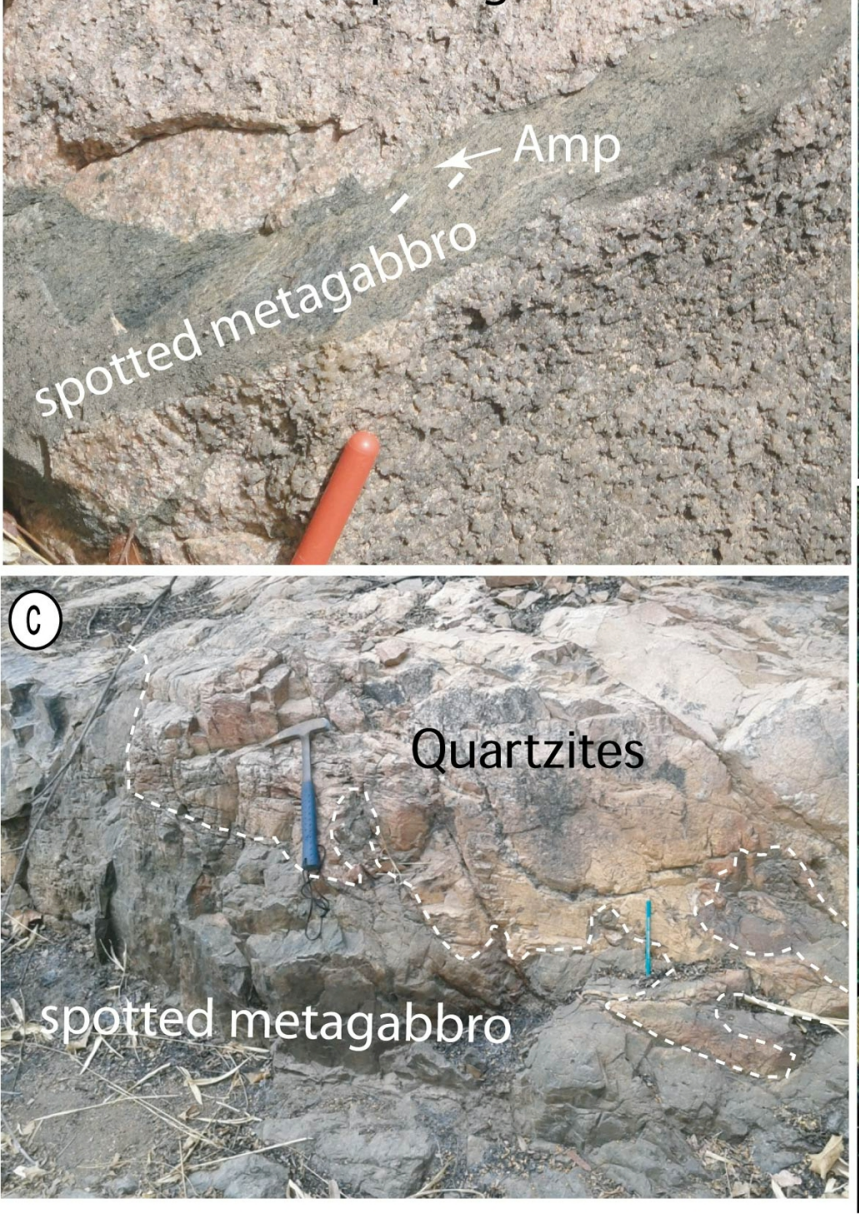

2. the 65

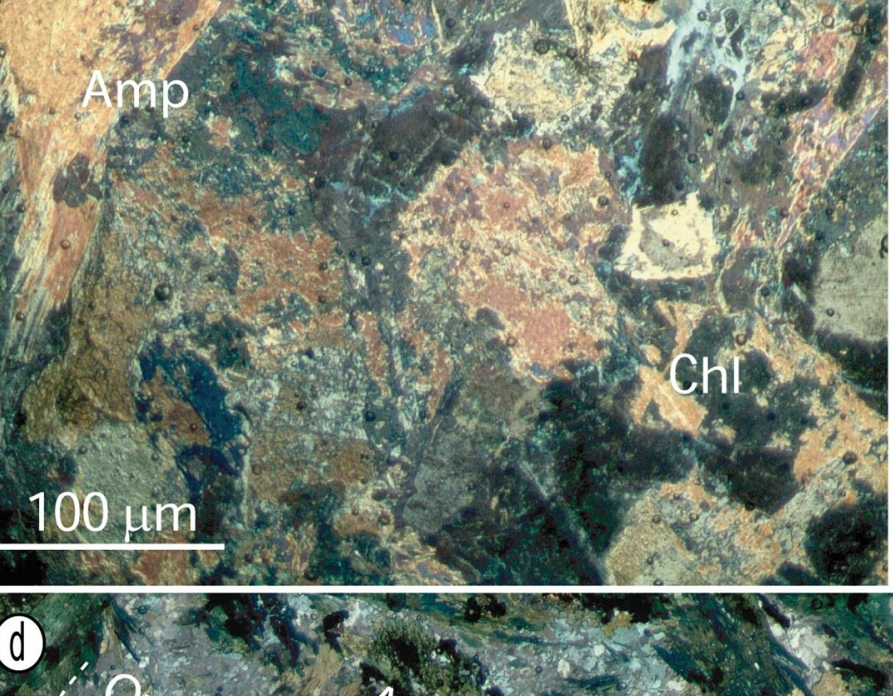

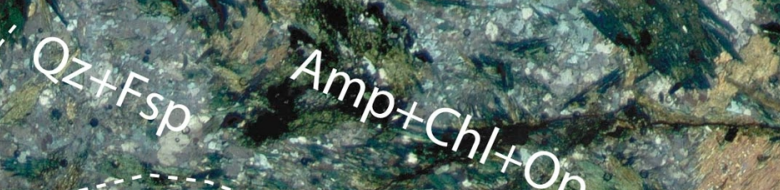

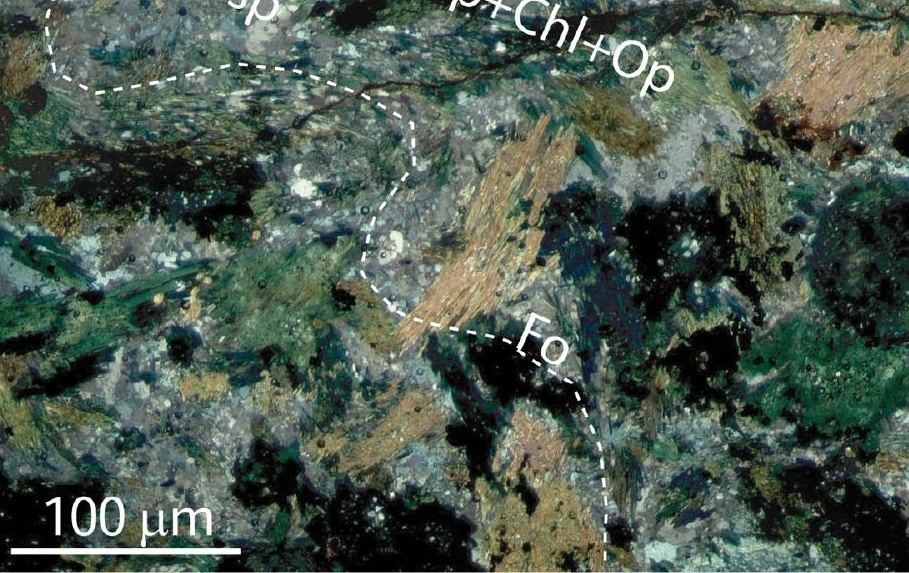


Tufs and rhyolitic

$\underset{0}{\times} \quad$ and rhyodacitic $\rightarrow$

है

lavas

Tufs and andesitic lavas

\section{Metabasalts} in pillow lavas

\section{Massive} metabasalts

Pegmatitic metagabbros

Isotropic metagabbros

\section{Layered} metagabbros

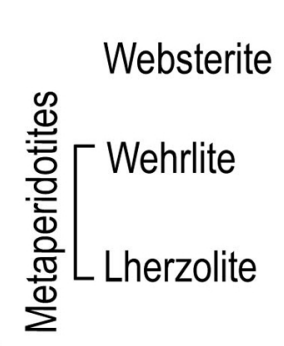

Spotted metagrabbros

Late tectonic granitoids $\pi 3$ (2090-2040 Ma)
Hornfels Syn-tectonic granitoids $\pi 2$ (2150-2100 Ma)

Early granitoids $\pi 1$ (2213-2160 Ma) 
Table 1. Previous geochronological data in Mako Supergroup

\begin{tabular}{|c|c|c|c|c|c|}
\hline & Lithology & Petrography & Method & Ages (Ma) & References \\
\hline \multirow[t]{5}{*}{ Mako Supergroup } & Ophiolitic complex & Basalt & $\mathrm{Sm} / \mathrm{Nd}(\mathrm{WR})$ & $2160 \pm 16$ & Boher (1991) \\
\hline & & Basalt & $\mathrm{Sm} / \mathrm{Nd}(\mathrm{WR})$ & $2197 \pm 13$ & Dia (1988) \\
\hline & & Basalt & $\mathrm{Pb} / \mathrm{Pb}(\mathrm{WR})$ & $2195 \pm 11$ & Dia (1988) \\
\hline & & Basalt & $\mathrm{Sm} / \mathrm{Nd}(\mathrm{WR})$ & $2063 \pm 41$ & Abouchami et al. (1990) \\
\hline & Mixed volcanic complex & Andesites & $\mathrm{Sm} / \mathrm{Nd}(\mathrm{WR})$ & $2160 \pm 16$ & Boher (1991) \\
\hline \multicolumn{6}{|c|}{ Badon-Kakadian batholith intrusions in Mako } \\
\hline & Granitoid & Granite & $\mathrm{Rb} / \mathrm{Sr}(\mathrm{WR})$ & $2199 \pm 68$ & Bassot and Caen-Vachette (1984) \\
\hline & Granitoid (Laminia) & Granodiorite & $\mathrm{Pb} / \mathrm{Pb}(\mathrm{Zr})$ & $2105 \pm 8$ & Dia et al. (1997) \\
\hline & Granitoid (Kaourou) & Granodiorite & $\mathrm{Pb} / \mathrm{Pb}(\mathrm{Zr})$ & $2138 \pm 6$ & Dia et al. (1997) \\
\hline & Granitoid (Kaourou) & Orthogneiss & $\mathrm{Pb} / \mathrm{Pb}(\mathrm{Zr})$ & $2079 \pm 6$ & Dia et al. (1997) \\
\hline & $\begin{array}{l}\text { Layered plutonic complex } \\
\text { (Sandikounda) }\end{array}$ & Layered gabbro & $\mathrm{Pb} / \mathrm{Pb}(\mathrm{Zr})$ & $2158 \pm 8$ & Dia et al. (1997) \\
\hline & & Tonalite gneiss & $\mathrm{Pb} / \mathrm{Pb}(\mathrm{Zr})$ & $2194 \pm 4$ & Dia et al. (1997) \\
\hline & & Tonalite gneiss & $\mathrm{U} / \mathrm{Pb}(\mathrm{Zr})$ & $2194 \pm 4$ & Gueye et al. (2007) \\
\hline & & Diorite gneiss & $\mathrm{Pb} / \mathrm{Pb}(\mathrm{Zr})$ & $2202 \pm 6$ & Dia et al. (1997) \\
\hline & & Amphibolite & $\mathrm{Sm} / \mathrm{Nd}(\mathrm{WR})$ & $2157 \pm 67$ & Dia (1988) \\
\hline & Granitoid (Mamakono) & Granodiorite & $\mathrm{Pb} / \mathrm{Pb}(\mathrm{Zr})$ & $2076 \pm 3$ & Hirdes and Davies (2002) \\
\hline & Granitoid (Mamakono) & Granodiorite & $\mathrm{U} / \mathrm{Pb}(\mathrm{Zr})$ & $2067 \pm 12$ & Gueye et al. (2007) \\
\hline & Granitoid (Badon) & Granodiorite & $\mathrm{U} / \mathrm{Pb}(\mathrm{Zr})$ & $2213 \pm 3$ & Gueye et al. (2007) \\
\hline & Granitoid (Tinkoto) & Granodiorite & $\mathrm{U} / \mathrm{Pb}(\mathrm{Zr})$ & $2074 \pm 9$ & Gueye et al. (2007) \\
\hline & Granitoid (Soukouta) & Granodiorite & $\mathrm{U} / \mathrm{Pb}(\mathrm{Zr})$ & $2142 \pm 7$ & Delor et al. (2010) \\
\hline
\end{tabular}

Zr: zircon, WR: whole rock 
Table 2. Mineral assemblages of amphibolites and chloritoschists of Mako

\begin{tabular}{|c|c|c|c|c|c|c|c|c|c|c|c|c|}
\hline & Amp & $\mathbf{P I}$ & Kfs & $\mathbf{P x}$ & Grt & $\overline{\text { Qtz }}$ & $\mathbf{E p}$ & Chl & Bt & Ms & Ca & IIm \\
\hline \multicolumn{13}{|c|}{ Amphibolites } \\
\hline $\mathbf{A L}$ & + & + & + & + & - & ++ & ++ & ++ & - & ++ & ++ & ++ \\
\hline AS & + & + & + & + & - & ++ & ++ & ++ & - & ++ & ++ & ++ \\
\hline OG & + & ++ & + & - & - & + & ++ & ++ & + & ++ & ++ & \\
\hline \multicolumn{13}{|c|}{ Chlorito-schists } \\
\hline CS & ++ & + & + & - & - & ++ & ++ & ++ & - & ++ & ++ & ++ \\
\hline TR & - & ++ & + & - & - & + & & - & - & ++ & ++ & ++ \\
\hline MB & ++ & ++ & & + & - & ++ & ++ & ++ & - & ++ & ++ & \\
\hline MG & ++ & ++ & & + & - & ++ & ++ & ++ & - & ++ & ++ & \\
\hline $\mathbf{U B}$ & ++ & & & + & - & ++ & ++ & ++ & + & ++ & ++ & ++ \\
\hline
\end{tabular}

$(+)$ primary texture; $(++)$ secondary texture; (-) lacking

Mineral abbreviations following Kretz (1983) and Whitney and Evans (2010); AL : layered amphibolites ; AS : spotted amphibolites ; MB : metabasalts : MG : metagabbros; OG : orthogneiss of Soukourtou; TR : rhyolitic tuffs of Mako ; CS : chloritoschists; UB : ultrabasites. 